University of New Hampshire

University of New Hampshire Scholars' Repository

Psychology Scholarship

College of Liberal Arts (COLA)

$1-1-2015$

\title{
Getting the message: The adaptive potential of interpersonal judgments
}

John D. Mayer

University of New Hampshire, Durham, jack.mayer@unh.edu

Kimberly G. Phillips

Amy Barry

Follow this and additional works at: https://scholars.unh.edu/psych_facpub

Comments

(CAPA, 2015. This paper is not the copy of record and may not exactly replicate the authoritative document published in the APA journal. Please do not copy or cite without author's permission. The final article is available, upon publication, at: https://dx.doi.org/10.1037/gpr0000025

\section{Recommended Citation}

Mayer, J.D., Phillips, K. \& Barry, A. (2015). Getting the message: The adaptive potential of interpersonal judgments. Review of General Psychology, 19, 39-51.

This Article is brought to you for free and open access by the College of Liberal Arts (COLA) at University of New Hampshire Scholars' Repository. It has been accepted for inclusion in Psychology Scholarship by an authorized administrator of University of New Hampshire Scholars' Repository. For more information, please contact Scholarly.Communication@unh.edu. 
RUNNING HEAD: INTERPERSONAL JUDGMENTS AS SOCIAL MESSAGES

\title{
Getting the Message: \\ The Adaptive Potential of Interpersonal Judgments
}

\author{
John D. Mayer \\ Kimberly G. Phillips \\ Amy Barry \\ University of New Hampshire
}

\begin{abstract}
According to the Social Message Model, interpersonal judgments are transactions in which judges convey important social messages to the individuals they evaluate (the targets); targets can then respond to the judgments in more or less adaptive ways. We argue that judges' opinions emerge from their current concerns, be it to promote their own well-being, or to foster group cohesion. Targets of judgments can best interpret the meaning of a judgment they receive by understanding the judge's concerns, competence of the judge, and other qualities of the transaction. We suggest that judges and targets who are better able to reason about the judgment process are likely to change their behaviors more adaptively than people less able to reason in this area.
\end{abstract}

\section{Prepublication version of:}

Mayer, J.D., Phillips, K. \& Barry, A. (2015). Getting the message: The adaptive potential of interpersonal judgments. Review of General Psychology, 19, 39-51. 


\section{Getting the Message: The Adaptive Potential of Interpersonal Judgments}

The judgments that people make of one another come in a variety of forms and are a universal and inescapable part of the social environment in which we operate (Haselton \& Funder, 2006). Some judgments concern our age, race, gender, or other physical aspects; others concern our behaviors or our character. Some judgments are meant to be helpful; others are intended to hurt. We judge others in a variety of ways depending upon our concerns at the moment and on our context. We often perceive others automatically, as when an individual reminds us of someone we know and we assume the new person is in some ways like the person we are reminded of (Andersen \& Chen, 2002; Bargh, Lombardi, \& Higgins, 1988). Or, we may evaluate others planfully, selecting a friend with a great deal of forethought.

Commensurate with the prevalence of interpersonal judgments, a vast person perception literature concerns the mechanisms and processes by which we form impressions and categorize people (see, for example, Freeman \& Ambady, 2011; E. R. Smith \& Collins, 2009). We evaluate people according to their group memberships, as interpersonal relationship partners, as individuals with distinct personalities, and we compare people to ourselves and to one another (e.g., Fiske, 1993; Wood, 1989). The person perception literature teaches us about the efforts we make to perceive one another effectively, including the subtleties of inferring personality traits and the pervasiveness of bias and stereotypes (Fiske, 1993; E. R. Smith \& Collins, 2009; Swann, 1984).

Here, our purpose is to understand the adaptive function of judgments. We present a new model that helps us to understand where judgments come from and their adaptive potential both to enhance the social effectiveness of the judge and to guide the psychological behavior and growth of the individual being judged. Our "Social Message Model" concerns how judges evaluate target individuals and the messages they communicate about individual and social standards. The model depicts an alternating flow of interactions between the target and judge: first the target appears, then the judge evaluates the target and the target reacts; the interaction concludes as the judge appraises the effects of the judgment. Although in real life these processes may take place in different orders, we present them in one common sequence here for the purposes of exposition.

Given that we are discussing social messages, we focus on a judge's direct verbal communication of an evaluation to a target. Although that is our focus, portions of our model also may be generalizable to other circumstances, including judgments communicated to third parties as gossip, or through other social channels. It may be less applicable to judgments that remain the private opinion of the judge (Kenny \& West, 2010; Mayer \& Leichtman, 2012; Stiff \& Van Vugt, 2008).

Fiske (1992) has argued that social perception takes place to accomplish goals ("thinking is for doing.") We believe that judges' evaluations are purposive and we focus on the adaptive potential of these social judgments. Some key parts of the model include that (a) the judge draws on "areas of concern" to judge a target person, (b) the target benefits if he is able to reason well about the judgment in order to harness its adaptive potential, and (c) the judge observes the judgment's effects and may receive feedback as to the quality of the judgment she has made.

Our model regards the target individual as willing to learn about himself and about the standards by which he is evaluated. We acknowledge that targets of judgment may not always 
be open to such feedback. Each of us is judged with some frequency, and the experience isn't always pleasant. People are typically sensitive to negative evaluations - often reacting defensively and with considerable psychic pain (Baumeister \& Leary, 1995; Downey \& Feldman, 1996). Some individuals may become suspicious of nearly all judgments and reject most forms of feedback they receive. Yet for most of us, judgments provide an information-rich source of potential guidance for how we might live our lives, and both judges and targets stand to benefit from accessing this potential. By facilitating an understanding of some of the truly adaptive reasons for judgments (including judging ourselves), we hope to begin a process of supporting people as they receive and deliver interpersonal evaluations of one another.

As a first step in understanding the adaptive aspects of judgments, we present a model to depict the process. We employ a language of judging that includes elucidating a judge's area of concern, and the standards of judgment that people use, as well as some of the reasoning that targets employ to understand the usefulness of the judgment they face. Toward the end of the article, we point out that our model is sufficiently comprehensive to provide a new means of organizing the person-perception literature. Moreover, the model, as applied to personality psychology, provides a basis for understanding new ways to assess a person's overall functioning according to the standards they meet.

Following this introduction, Part 2 of this paper, "Overview of the Social Message Model," briefly describes the model. In Part 3, "The Social Message Unfolds," we describe each stage of the judgment process. We treat some stages of the model briefly such as "The Target is Present" and "The Initial Reaction" because these areas will be readily grasped and already have been explored in depth by psychologists. Other sections such as "The Judge's Concerns" are developed more fully because they describe more novel perspectives on judgments made possible by the model itself.

In "The Judge's Concerns," we argue that the meaning of a judgment depends, in part, on the "area of concern" of the judge, by which we mean the judge's mental set or standpoint. For example, Brewer and Gardner (1996) argued that our judgments of people change depending on whether we are concerned with our selves or our social groups, and Tetlock (2002) pointed out that we may often take on the social role of a prosecutor or a politician when we judge. We examine a wide range of "areas of concern" to account for the variety of judgments in which we engage.

Many researchers have documented that judgments vary in their accuracy. In our section on "Reasoning about Judgment," we point out that a target must decide how accurate a real-life judgment is (e.g., Fiske, 1993; Funder, 2001; Kenny \& West, 2010). The target person will need to assess a judge's biases relative to the judgment that is made. On that basis, the target then decides which social messages to attend to and which to reject.

In our sections on "Adaptation," we examine the adaptive purpose of interpersonal judgments. Judges maximize the usefulness of their messages when their information is accurate and shared with care and social skill. Judges who do this well gain status because evaluating others well reflects positively on them and facilitates their social relationships. Targets, in turn, potentially benefit by using a judge's standards to learn about themselves. To do this successfully, however, they must exercise skill at distinguishing good judgments from those that are overly swayed by bias or error (e.g., Stern, West, \& Schoenthaler, 2013).

In the discussion, we summarize our theory and discuss several areas of future research that emerge from the model. One research direction concerns people's abilities to cope with and to evaluate the messages of judgments; another direction concerns using social standards as a 
tool for improving the assessment of personality functioning. Finally, in our concluding comments we note the model's potential contributions to understanding social messages more generally.

\section{Part 2: Overview of the Social Message Model}

Each of us is judged frequently: we simply need to "be there" within a person's attentional focus to receive an evaluation. The Social Message Model begins with the judge recognizing our presence, either in the flesh or in memory. Sometimes we may even be judged for being absent, as when missing a meeting. The target's presence is depicted in the left-hand column of Figure 1. That presence sets off a series of reactions - an initial judgment, perhaps, that begins a negotiation with others regarding who we are (Hardin \& Higgins, 1996; Haselton \& Funder, 2006). Figure 1 provides a schematic overview of the alternating process that makes up the judgment. The sequential nature of the diagram is a simplification, of course, as many of the events may unfold simultaneously or in a somewhat different order. Regardless, the model identifies key elements of the process.
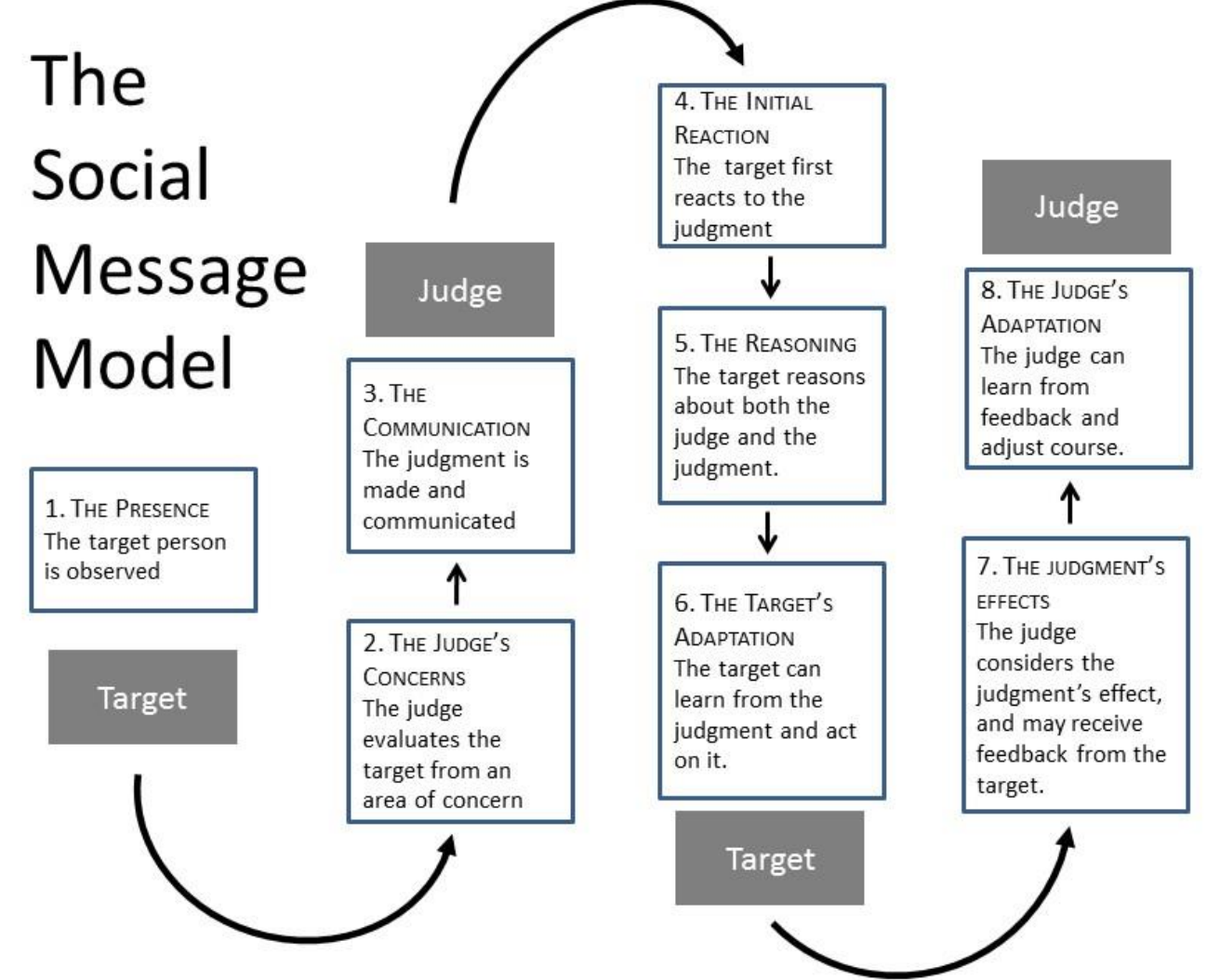

Figure 1: Overview of the Social Message Model. The Social Message Model describes interpersonal judgments as an alternating process between the target and judge in which the judge communicate key social information from to the target (and the target sometimes communicates back to the judge). The model organizes the elements of the judgment transaction, explaining how judgments originate and how they can be evaluated and used by targets and judges. This bird's-eye view of interpersonal judgments illustrates how the social messages in judgments can be deciphered and used (or discarded) advantageously. 
In the role of a judge, we evaluate others, from children in the school-yard to those caught in the spotlight of national scandals, for their significant personality characteristics, appearance, and acts (e.g., Kamins \& Dweck, 1999; Kipnis, 2010; Olson \& Dweck, 2009). Our judgments can take diverse forms, including gossip, labeling, and legal decisions (Baumeister, Zhang, \& Vohs, 2004; Ben-Ze'ev, 1994; Kane, 1992; Link \& Phelan, 2001). We often communicate our judgments_-providing feedback regarding how others are perceived and behaving.

The judge's evaluations may be potentially informative about his values in that the judge holds his target to standards that are on his mind. For example, if the judge is interested in traditional sex roles, he might judge another person against such standards as whether she is feminine (Bem, 1984; Palomares, 2004; Spence, 1993); or if the judge values virtues, whether she is moral (Garcia, 1995; Haidt \& Baron, 1996; Haidt \& Joseph, 2004). From our earliest childhoods, we learn how to behave from the judgments of our parents, our teachers, and peers; we learn to discern which standards are important for us to follow (Maccoby, 2007; Smetana, 1999). Because individuals typically develop a sense of self-knowledge from relationships and depend upon the views of other people for their well-being, feedback from parents and others helps to guide our behavior (Baumeister et al., 2004; Hardin \& Higgins, 1996).

The Social Message Model specifies that the judge evaluates others depending upon her concerns at the moment (Figure 1, "The Judge's Concerns"). For example, a parent may express a judgment (e.g., "your shirt has a stain on it, please change before we leave..."), so as to guide a child toward better social conduct. That judgment can be conveyed in a supportive polite way (Figure 1, "The Communication") or in a less polite fashion. The target then reacts (Figure 1, "The Initial Reaction"). At least some of the time, incoming messages will be unwelcome: many of us dislike being challenged to meet standards that are imposed by other people, and few of us like being criticized.

We may follow certain standards willingly. The rule of law and many social conventions are reasonably clear, require little effort to comply with, and bring benefit to many (Freud, 1962; Rawls, 1971). Yet we may find that other social standards chafe, and we will choose to negotiate our adherence to them. The eminent psychoanalyst Charles Brenner once remarked "that conflict and compromise formation are...ubiquitous in mental life..." (Brenner, 2003p. 1094-1095), and this certainly is the case when it comes to choosing which standards to meet. People share many values in common, but they often assign different priorities to them (Schwartz \& Boehnke, 2004). Making decisions about which judgments are meaningful to us (Figure 1, "The Reasoning"), we reason about the content of a judgment as well as about the judge herself.

The Social Message Model assumes that judges "bring something to the table" by accurately perceiving a target person's traits and behavioral expressions. Funder (1995) has argued that accuracy of judgments is gauged in part from the convergence of criteria such as the target's self-estimate, peer judgments and behavioral indices. Research indicates some consistency across these sources. For example, Kenny and Albright (1987) found the agreement between judges (peers) and self-reports was between $r=.22$ and .65 depending upon the trait, and Kolar, Funder \& Colvin (1996) found relations of about $r=.28$ between peers and multiple behavioral criteria. These findings underscore that there is something to be gained from listening to judgments but also to recognizing that judgments can at times be flawed.

As targets of judgments, we assess their source, evaluate them for their helpfulness, and negotiate our response to them with the significant figures in our lives. In doing so, judgments 
provide target individuals with a path to greater self-knowledge and a vehicle for learning about others (Figure 1, "The Target's Adaptation"). It seems likely that people who make good use of how they are judged also experience an advantage in adaptation because they can use the information to guide their choices.

In the role of judges, we experience a reciprocal learning experience. We attend to how our evaluations are received (Figure 1, “The Judgment's Effects"), and this helps us learn about our credibility as a commentator, our accuracy, and our social status and reputation. If our standards are continuously rejected or ignored, we might elect to better explain ourselves, or shift our standards in a more normative fashion so as to enjoy more respect and influence (Figure 1, "The Judge's Adaptation"). Judges and targets both aim to gain favor from others for the sake of living according to community values (Clark \& Mills, 2012).

To better understand the adaptive potential of judgments, it helps to appreciate the multiple areas of a person's life to which the judgments can apply. To this end, we include in the next section a consideration of the judge and "The Concerns" that give rise to judgments.

\section{Part 3: The Social Message Unfolds}

\section{The Target is Present}

Each of receives feedback from the people around us as to our qualities. Our mere presence is typically sufficient to be noticed, and once noticed, we may be judged to varying degrees and according to many standards (outlined below). We are just a passing stranger to some - an unremarkable figure strolling through a grocery store or waiting at a bus stop - in which case a judge's evaluation may be mostly to ignore us so as to focus on more important matters (Fiske \& Taylor, 1991). Each of us, however, becomes central to certain people's lives, in which case we are likely subject to greater scrutiny.

\section{The Judge's Concerns}

Judges evaluate individuals according to whether the target has violated, met, or exceeded important standards of conduct. As judges, we employ standards according to what we are thinking about - our chronically-accessible constructs, goal pursuits and current concerns (Kawada, Oettingen, Gollwitzer, \& Bargh, 2004; Klinger \& Cox, 2004; Kopetz, Kruglanski, Chen, \& Orehek, 2008).

As people judge, their standards vary according to the perspective they take (Brewer \& Gardner, 1996; Jarymowicz, 1992; Luhtanen \& Crocker, 1992). Brewer and Gardner (1996) collected evidence that people who are self-concerned judge others more in terms of their traits, whereas people concerned with their group memberships judge others more in terms of group status. Because a person's cognitive capacities are limited, an individual judge will often be engaged with one concern at a time when evaluating others. For example, a $10^{\text {th }}$ grader will be engaged with her needs as a student during a science test and may evaluate her fellow test-takers according to the degree of competition they pose to her, their anxiety or their smugness. After school at softball practice, she will be more focused on her teammates' roles as softball players and evaluate them by how well they conform to the coach's demands. Within a given area people may enter into more specific mindsets. For example, that same student might evaluate her team members from a prosecutorial mindset or with the finesse of a politician (Tetlock, 2002).

Personality and its surrounding systems. Here, we expand on these earlier views of the judge's concerns and role-taking. We begin by considering a recent portrayal of personality amidst its neighboring systems, including the brain, setting, and groups, as indicated in Figure 2. 
Personality is at the center and is surrounded by the brain beneath it and by such outer systems as the person's setting and situations to the right. These systems are mapped in Figure 2 according to two dimensions: a biopsychosocial (molecular-molar) dimension running vertically, and an inner-outer dimension that runs horizontally (Mayer, 2005). Social groups (at the top) contain both the individual and outer situations. This diagram taps a consensus in the field in its use of the molecular-molar dimension to distinguish personality from the brain below and social groups above. The addition of the second inner-outer dimension is newer, and although some researchers have has raised concerns chiefly as to whether it is needed (e.g., Sheldon, (2011), we believe the inner-outer dimension provides a useful clarification of the distinction between inner personality and its expression (Mayer \& Lang, 2011; McAdams \& Pals, 2006; Mischel \& Shoda, 1995).

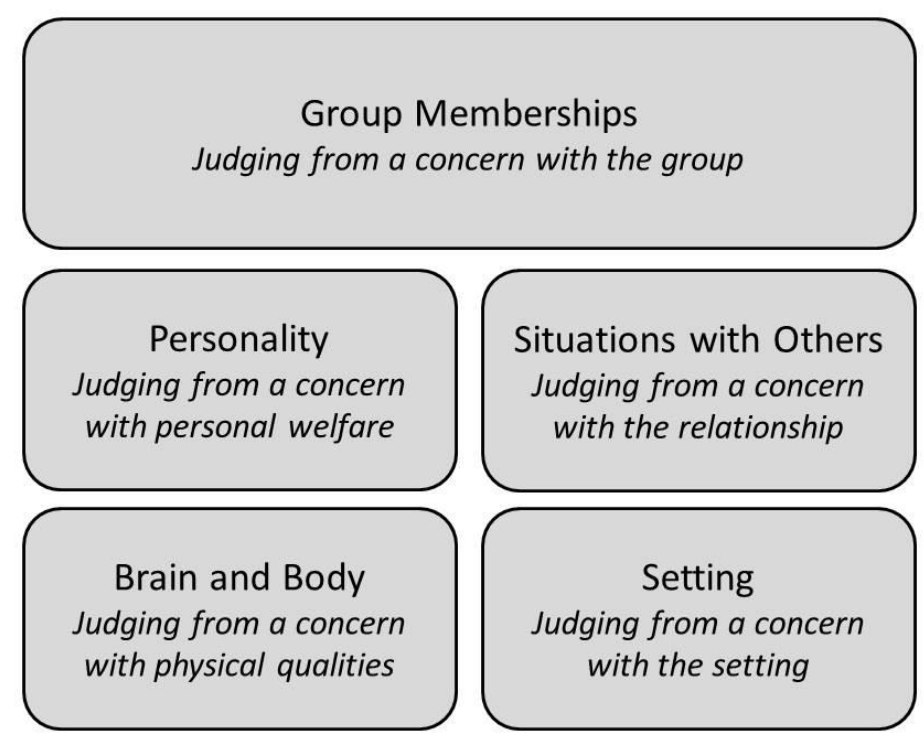

Figure 2: Personality, its Surrounding Systems, and Sources of Judgmental Thinking. Personality is depicted as surrounded by four neighboring systems with which it interacts. Along a biopsychosocial dimension (represented along a vertical axis), personality emerges from the brain and body (bottom left), and is a part of groups (top). A second inner-outer dimension (represented horizontally) separates the inner person (left) from outer settings and situations (right). The settings and situations also are part of larger social groups. People may judge from multiple standpoints, such as those concerning their groups, inner needs, or physical well-being, as described in the figure, and elaborated in the text. Figure adapted from "A tale of two visions: Can a new view of personality help integrate psychology?," by J. D. Mayer, 2005, American Psychologist, 60, 294-307, p. 297, Copyright 2005 by the American Psychological Association.

Returning to the diagram, Brewer and Gardner's individual self is the "personality" as depicted in the diagram. Their "group self" reflects personality's concern with a social group (Figure 2, top). The diagram suggests that, in addition to an individual and group concern, people's judgments are influenced by the target's physical qualities, settings, and situations.

Areas of concern. Brewer and Gardner (1996) referred to the group and individual selves as "self representations," but adding settings and situations to the conversation, we will modify their terminology to speak of areas of concern. In our conceptualization, "concerns" can emerge automatically as a person's thoughts are primed by a given situation, or can be called upon as a part of intentional thought; either way, our intent is simply to indicate that judgments emerge 
from a person's particular standpoint (e.g., concern with a person's group or setting, Bargh et al., 1988; Hardin \& Higgins, 1996). This process can be briefly summarized here as:

People judge others in reference to areas of concern and the standards associated with a given area. These areas of concern include (among others) inner states, physical needs, and social groups. A person's concern with an area means the individual is monitoring or activating thoughts related to that area. Once an area of concern is activated, the person's judgments are likely to reflect standpoints related to the area. So, for example, a judge whose concern is with group identity will judge a person according to their how well that peer conforms to the group's norms.

A judge will shift her concerns over time. For example, a high school student who is concerned with maintaining her status among her softball teammates (Figure 2, "Group Memberships") might judge a team-member, Samantha, from the standpoint of her contribution to the team-as "a good outfielder." If the student is engaged with her insecurities (Figure 2, "Personality"), she might instead promote her own self-esteem with the comparison that Samantha is "not as good a hitter as I am." Alternatively, if she is concerned about maintaining a personal relationship with Samantha (Figure 2, "Situation with Other[s]"), she may judge Samantha fondly, from the standpoint of "my friend who studies with me for biology." These concerns are important because they motivate judgment in specific ways.

Applying the Social Message Model to personality and its neighboring systems. Figure 3 describes the two sides of judgment - judge and target - at these different areas of concern. Each concern elicits a different kind of judgment and specific areas of psychological research have emerged that study each area.

Judging from a concern with physical qualities. For example, when meeting a new acquaintance, a judge may form a first impression based on the other person's physical appearance (Naumann, Vazire, Rentfrow, \& Gosling, 2009). According to present-day evolutionary theory (specifically, the adaptionist perspective), people evolved so as to find those individuals who possessed adaptive physical qualities as more attractive than others (Andrews, Gangestad, \& Matthews, 2002; Gangestad \& Scheyd, 2005). Greater seeming attractiveness, in turn, was a signal of a better "underlying quality or condition," in the sense of being free from disease, better able to reproduce, passing along fitter genes, and raising offspring. From a social standpoint, cultures develop and teach what is beautiful and those teachings may affect a person's status as well (Langlois et al., 2000; Solomon, Ashmore, \& Longo, 1992). This concern over appearance is described in Figure 3 ("Physical" left).

The recipient of such judgments, in turn, may benefit from such information by using it to adjust his appearance to the degree that it is possible (or desired). At the same time, the recipient uses the information to shape an understanding of his level of physical desirability as a partner or mate, including the range of appearance-related physical qualities he can realistically expect to provide to a partner (Figure 3, "Physical" right). Although the evaluation may be disliked, accepting such feedback (if valid) can help individuals adjust their social relations accordingly, striving to make use of their high physical desirability, or compensating for lower physical desirability by excelling in other areas. In other words, the judgments convey important adaptive information about one's physical presence. 


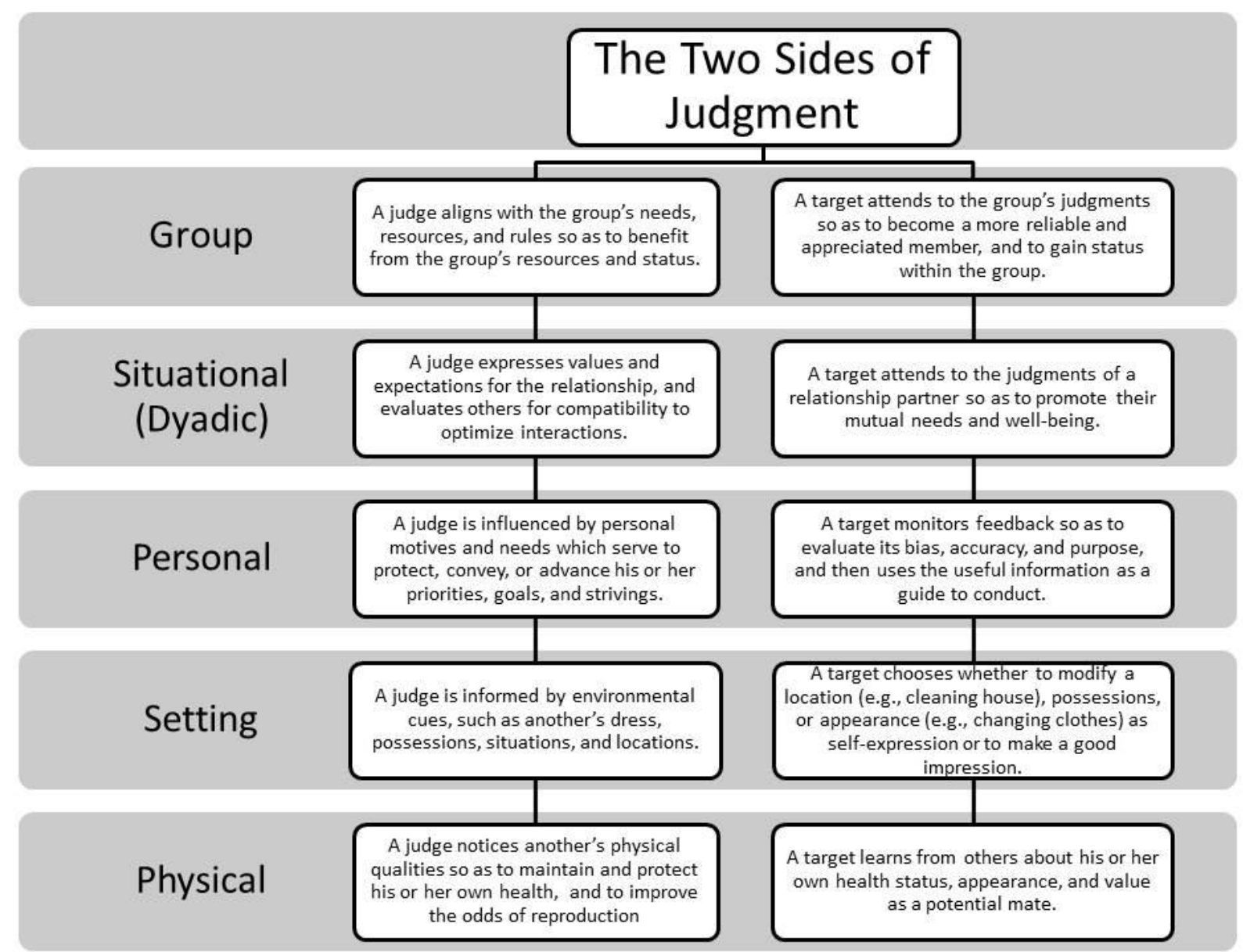

Figure 3: The Two Sides to Judgment. The areas of concern provide insight into why people judge (left column, "The Judge") and how people can use such judgments adaptively (right column, "The Target"). These judgments potentially are informative to people and can assist their social interactions, although it is also true that the judgments can fail in important ways, causing misdirection and distress (see text).

Judging from a concern with the setting. A judge also might be engaged with her setting, where the term "setting" is roughly analogous to the stage setting of a theatrical production, including the property (props) and costumes used for the show (Figure 3, "Setting"). People judge each other using cues from their dress, possessions, neighborhoods, and homes, among other qualities of the setting, in part because these may become a shared environment if a partnership develops (e.g., Phillips \& Smith, 2008).

Possessions and locations provide clues about the person. For example, people whose possessions include tablecloths, good dishes, clothing and vitamins provide clues that they take better care of themselves, seek to be with others and have generally higher self-esteem than others (Gosling, Ko, Mannarelli, \& Morris, 2002; Mayer, Carlsmith, \& Chabot, 1998). Judging from the setting-related perspective can help us to better understand others, how they take care of themselves, and where they like to be.

People who are judged according to their setting, in turn, learn about the effects that their dress, possessions, and environments have on others. For example, they may learn how to dress appropriately for certain situations, to purchase objects that convey their identity in ways they 
wish and to seek settings that respected others will find appealing (Oyserman, 2009). Once again, the judgments in this realm convey adaptive clues as to one's behavior.

Judging from inner personal concerns. Judges may also be concerned with their feelings and judge others from a self-focused standpoint (Figure 3, "Personal" left). An executive may try to gauge whether a supervisor is a reliable reporter about how she manages her team, or is so defensive as to distort her self-descriptions (Bond, Gardner, Christian, \& Sigal, 1983; Vaillant, Bond, \& Vaillant, 1986). Or, a manager may judge a coworker so as to predict the coworker's behavior in a key situation (Funder, 1995, p. 652; Swann, 1984, p. 458).

Although many people focus on accuracy as they judge (Letzring, 2008), people who are self-focused also may be motivated by needs beyond predictive accuracy: they may form "downward comparisons" to those who are similar but less well-off so as to make themselves feel better (Festinger, 1954; Wood, 1989). Another person may compare herself "upward" to a similar acquaintance who is doing a bit better so as to try to master the skills she possesses. This and other comparisons may often be automatic and non-conscious. Another example of judgment that is influenced by personality processes is mood-congruent processing in which people's current moods color their evaluations of others, with people in positive moods seeing others in a positive light and people in bad moods attending more to the negative (Forgas \& Bower, 2001). Even if the judge is motivated by a bad mood or a downward comparison to exaggerate a defect in the recipient, the information may be useful to the target if it illuminates an area for possible improvement and if the target is motivated to hear it (Figure 3, "Personal," right).

Judging from a concern with the relationship. Like judging from a personal standpoint, judging that is influenced by a relationship can be motivated by accuracy or by strategic concerns that may lead to biases. A person may want to accurately evaluate a partner to anticipate her behavior, for example her reliability at work (Figure 3, "Situational," left). Other relationship-focused judgments involve evaluating others' social roles and the skills with which they fulfill a certain role, for example, how well a principal leads a school (Buhrmester, Furman, Wittenberg, \& Reis, 1988; Gresham, Elliott, Cook, Vance, \& Kettler, 2010). Leaving behind accuracy, we may judge for strategic gain. Altercasting, for example, involves judging another person expressly so as to adjust a social hierarchy, often promoting one person's status over another's. Examples of altercasting occur frequently in the media during partisan debates, when one politician might refer to another as a "tea-party extremist" or a "tax-and-spend liberal" (Beckhouse, Tanur, Weiler, \& Weinstein, 1975; Pratkanis \& Gliner, 2004). More prosaically, a young woman who introduces a family member as "my little sister" is signaling how she might want others to view that sister. Other tactics for social influence include the strategic use of flattery, politeness, and loyalty (Chan \& Sengupta, 2010; Vonk, 2002).

As with judgments from other areas of concern, some dyadic judgments provide genuine feedback. Others, such as altercasting, may reflect strategic ends - to adjust someone's position in a status hierarchy if one is the target of competition and envy. Amid a sea of possible influences on a judgment, a target in a dyad who hopes to learn about himself must try to grasp the judge's intentions as best as possible (Figure 3, "Situational," right).

Judging from a concern with the group. People in a group often seek to promote the group's interests by evaluating other members' contributions or loyalty to the group (Tajfel, 1982) (Figure 3, "Groups," left). Deciding whether someone is a good group member often is key to whether the individual is accepted by other group members or not (Baumeister \& Leary, 1995; Haidt \& Joseph, 2004). From the standpoint of the person who is judged, monitoring such evaluations is important to maintaining her status within a group; understanding others' 
perceptions helps her preserve her acceptability as a group member, and advance in the group's hierarchy if she so wishes.

\section{The Communication of a Judgment}

After a judgment is formulated, it is shared-and obviously, this can be done with more or less clarity, and more or less harshly (Figure 1, "The Communication"). Judges may use so much politeness and tact that the target misses the message, or use no tact or politeness and needlessly offend the message recipient (Brown \& Levinson, 1987; Watts, 2003). Judges also can go awry if their evaluations of a person are biased by extraneous influences. In such instances, the adaptive quality of the judgment may be attenuated, and the communication may be more maladaptive than not. Some of this will depend on the recipient's reactions.

\section{The Initial Reaction}

According to the Social Message Model, we can benefit from monitoring the judgments we receive to some degree; to ignore others' comments is to become socially unmoored and potentially isolated. But monitoring such information can be challenging at times. Interpersonal judgments contain hot information in the sense that they often elicit an emotional response from the target - from warming the heart to making the blood boil (Abelson, 1963; Mayer, 2014). People may reject a judgment out of defensiveness or from customary disagreeableness (Settles et al., 2012; Vaillant 2012). Strong reactions may also be more likely among those with "rejection sensitivity" (Downey \& Feldman, 1996). These individuals develop expectations of being judged poorly and of being rejected by others. As such, they react heatedly to the possibility of rejection, expressing either defensive withdrawal or lashing out with anger, bitterness, or aggression (Downey \& Feldman, 1996). For such individuals, the loss of social inclusion that may result from judgments can be devastating, ultimately precluding the enjoyment of valued social relationships (Downey \& Feldman, 1996; B. London, Downey, Bonica, \& Paltin, 2007).

On the positive side, if we are highly motivated to be well judged, a sense of challenge may spur us to ever-higher levels of performance (Skinner \& Brewer, 2004; C. A. Smith, Haynes, Lazarus, \& Pope, 1993). Meeting an important and unusually challenging goal can foster hard-earned satisfaction and sometimes improve our self-esteem (Olson \& Dweck, 2009). These judgments, positive or negative, elicit our attention and concern in part because they elicit such strong feelings. Either way, accessing the adaptive information contained in a judgment is not an easy task.

\section{The Target's Reasoning about the Judge and Judgment}

Targets of judgments need to decode the information communicated by the social message, according to the Social Message Model. Targets who are better able to reason about the judgments made of them are more likely to act on those evaluations adaptively than people less able to reason in this area. Many of the issues facing the target are illustrated in Figure 4.

An example using Figure 4 can help to clarify the process: Jerry has been playing trumpet for many years and wants to try out for the city orchestra. To begin with the judgment itself (Figure 4, top), he invites his former instructor to give him feedback on an audition piece he has prepared, and she regretfully shares her view that he lacks the skill to be part of the orchestra. That night, Jerry thinks about his instructor's assessment and weighs how much her judgment should influence his course of action.

Reasoning about the message. Jerry begins by reasoning about the message (Figure 4, top right), asking himself whether, he has received a similar message in the past (Figure 4, right 
side, first box). In Jerry's case, other musicians have remarked favorably on his playing, so the answer is no; he needs more data. Part of that might come from examining the judge herself.

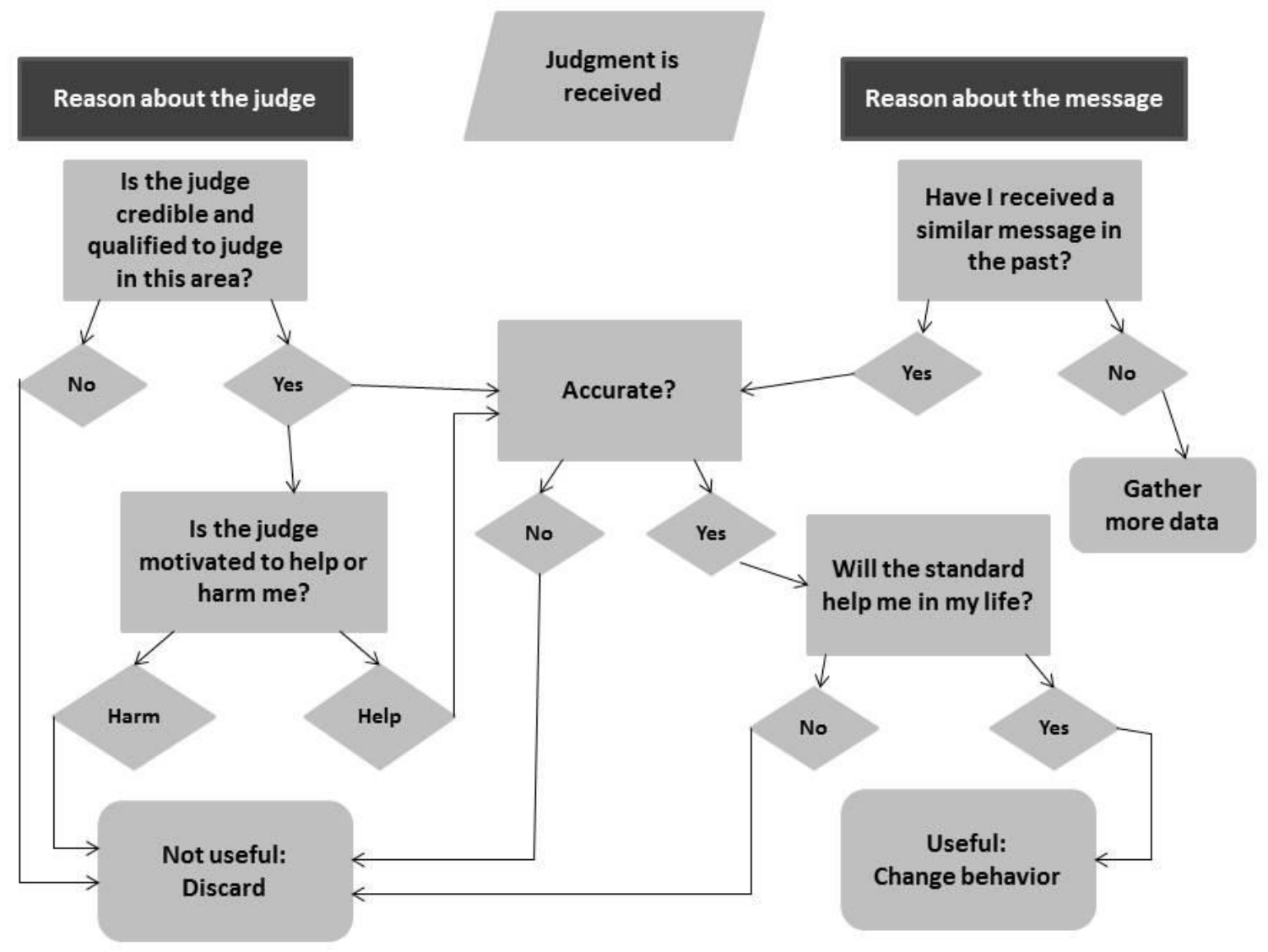

Figure 4: The Target Reasons about a Judgment's Usefulness at Multiple Decision Points. The target of a judgment evaluates the accuracy and relevance of incoming social messages by processing information about both the judge (left side) and the message itself (right side). The ultimate decision point is whether to accept the substance of the judgment, leading to a change in self-concept and/or behavior, or to discard it. The exact steps of the reasoning process will vary, and this figure represents one example of the criteria and trajectory a target may use.

Reasoning about the judge. Certain judges are particularly knowledgeable; teachers know more about one's abilities in the area they teach than do others (Dunning, 2005). Jerry decides his former instructor is credible and is qualified to judge his musical abilities, as she has heard him play many times in the past, though not as often recently. Targets will do better if they weight feedback from good judges who are relatively free of bias more heavily than comments from judges who are socially insensitive or lack credibility (Figure 4, left side, first box). Therefore, Jerry also asks, "Is this judge motivated to harm me or to help me?" (Figure 4, left side, second box). Jerry has always considered himself subordinate to his music teacher. His former instructor had not been one to heap praise on her students, but he had thought of her as fair and supportive. It occurs to him now that she might be envious of his talent, as she had never had the opportunity to play in the orchestra herself.

The outcome of Jerry's reasoning process will ultimately help to determine his course of action. If he decides that his former instructor's judgment is not advantageous to him, he may 
proceed to audition for the orchestra despite it and fulfill his ambition as a musician (or end up investing his time only to be rejected). If, on the other hand, he reasons that her opinion is valid, perhaps because it corresponds to that of a few others in whom he has confided, he may seek a different pursuit within the performing arts and devote more energy and effort toward a more attainable goal. According to the Social Message Model, a target makes a specific choice among alternatives by reasoning about how well the alternative will promote the individual's personal, interpersonal, and social goals.

\section{The Adaptive Potential for the Target}

A judgment can be a powerful tool for a target who is open to such information and has the capacity to process it. Individuals who understand the substance of judgments can successfully pursue meeting the standards that best align with their personal values and goals (Ryan \& Deci, 2000). , assimilating information from a judgment or discarding it. Those who do not or cannot reason as successfully about judgments may feel less self-determined or may experience dissonance from striving to meet standards that do not match their self-concepts or their aspirations (Ryan, Huta, \& Deci, 2008). The messages conveyed by the judgment transaction reveal a depth of information about the guidelines, preoccupations, goals and values that people apply with varying skill in choosing how to live.

\section{The Judgment's Effects}

Judges are often able to observe how targets respond to the evaluations they have made, and sometimes they receive direct feedback from targets. A friend may continue to wear an outfit even after being told it did not match, or a student may tell a teacher that the grade on his paper is clearly biased and unfair. In either case, judges who attend to the effects of their judgments can learn valuable information about how they, in turn, are perceived.

\section{The Adaptive Potential for the Judge}

As judges, our reputations (wise or biased; meddling or helpful) affect our credibility and social status (Letzring, 2008), which in turn determines the scope of our social influence.

There are "good judges" in Funder's (2001) terms, whose accuracy may lead them to be more socially adapted, to form better relationships and sometimes to be better regarded by others (Letzring, 2008). A good judge may find that being viewed as such is a boon, generating the trust and admiration of others. Such individuals may be sought for roles in which superior judgments of others are of direct use as in areas of human resources, counseling, and positions of leadership (Christian, Edwards, \& Bradley, 2010; M. London, 2002).

Dimensions related to the "good judge" include psychological mindedness, emotional intelligence and personal intelligence, among others (Christiansen, Wolcott-Burnam, Janovics, Burns, \& Quirk, 2005; Funder, 2001; Letzring, 2008; Mayer, Roberts, \& Barsade, 2008; Mayer, Panter, \& Caruso, 2012; McCallum \& Piper, 1990). Individuals with these interests and abilities may better communicate their evaluations of others with care and tact. Effective communication also may help to protect these judges from some of the more negative reactions with which a judged target may respond (Bonnefon \& Villejoubert, 2006). Judges who make their reasonable evaluations of others' behaviors known can smooth their own social relations because the recipients of such judgments know what the judge expects and may find that acceptable - even if they don't always agree.

\section{Discussion}

The model developed here provides a bird's-eye view of interpersonal judgments as communicating key social information from judges to targets and sometimes back again as an 
evaluation of the judge's capability. People are judged repeatedly against many standards and in consequential ways, we argued. The information conveyed by such judgments reflects the judge's varying standpoints, including socially-shaped concerns with one's physical body, psychological self, setting, dyadic situations, and group memberships. Using the Social Message Model, we provided a description of how judgments originate from these areas of concern and how they are received and evaluated by targets. Next, we focus on how the model can be put to use in specific contexts pertaining to the person-perception literature and personality measurement.

\section{"Areas of Concerns" and the Person Perception Literature}

One key point of our Social Message Model is that judges evaluate others according to standards from different areas of personality and its surroundings - areas of concern that span everything from self-concern to group identifications to evaluations of physical attributes and the social setting.

An intriguing application of the model is to use it to organize research in the area of person perception according to these same areas of concern that (the model states) everyday judges employ. For example, just as judges evaluate other people's extraversion, researchers have examined how people read personality traits in another person.

With Table 1, we illustrate how the model's five "Areas of Concern" provide a way to divide the person perception literature. The rows of Table 1 reflect the purposes of judging (left side), and to the right are illustrative studies. The "social comparison" literature, for example, describes judgments that emerge from concerns with the inner processes of personality (e.g., hoping to raise one's self-esteem); dyadic relationships involve judgments from the "altercasting" and relationship literatures (e.g., Beckhouse et al., 1975; Pratkanis \& Gliner, 2004). Concerns over group memberships draw on research on in-groups and out-groups (e.g., Tajfel, 1982). By 1993, Fiske (1993, p. 156) already referred to the "abundance of relevant work" in the area of person perception, so good organizations of this sprawling area are valuable to helping researchers locate its findings of interest.

\section{Extensions to Assessment and Clinical Psychology}

People are likely to vary in their capacity to identify the useful information in social messages. Some people who are less able to understand the messages involved might be inclined to accept almost all the judgments made of them, or inclined to dismiss them all, unable to reason effectively or sort the more from the less useful comments. By comparison, others may discern the message of the judgment and be able to infer the judge's concerns and make better decisions as to whether to accept or reject the information being conveyed (Christiansen et al., 2005; Letzring, 2008; Mayer et al., 2012).

For that reason, one application of the model is to develop scales that assess a person's ability to recognize the message in a judgment. In one possible approach, participants might read or view a description of a person and then read an evaluator's judgments of that person. The participant's job would be to identify the standards inherent in the judgment and whether they are helpful for the recipient to know about. Assessing a person's abilities to decipher judgments may be important to understanding a person's adaptive mental health (Mayer, 2014). If some people are better at assessing judgments than others on such scales, they may also show differences in their ability to accept and utilize judgment in real life. 
Table 1. Using Areas of Concern to Classify Representative Articles from the Person Perception Literature

\begin{tabular}{|c|c|}
\hline $\begin{array}{c}\text { Area of Concern when } \\
\text { Judging }\end{array}$ & Examples of Articles Specifically Relevant to the Area of Concern \\
\hline $\begin{array}{l}\text { Judging from a concern } \\
\text { with the group }\end{array}$ & $\begin{array}{l}\text { - Distinguishing in-group from out-group members (Gellner, 1983; Macrae \& } \\
\text { Bodenhausen, 2000; Phillips \& Smith, 2008; Tajfel, 1982; Taylor, 1981; Zubaran, 2009) } \\
\text { - Moral judgments of others (Haidt \& Baron, 1996; Haidt \& Joseph, 2004; Kohlberg, } \\
\text { 1964; Rawls, 1971; Schwartz \& Boehnke, 2004) } \\
\text { - Leader assessment (London, 2002) } \\
\text { - Schema-driven (Bem, 1984; Miller, 1984; Palomares, 2004; Spence, 1993) } \\
\text { - Reputation within the group (Smith \& Collins, 2009) }\end{array}$ \\
\hline $\begin{array}{l}\text { Judging from a concern } \\
\text { with the relationship }\end{array}$ & $\begin{array}{l}\text { - Strategies in altercasting (Pratkanis \& Gliner, 2004) } \\
\text { - Character-based judgment of third parties (general gossip/instruction) (Ben-Ze'ev, 1994; } \\
\text { Peterson \& Seligman, 2004) } \\
\text { - Characterizing traits (Bruner \& Tagiuri, 1954; Funder, 1995; Haselton \& Funder, 2006; } \\
\text { Klein, Cosmides, Murray, \& Tooby, 2004; Peterson \& Seligman, 2004; Swann, 1984) } \\
\text { - Evaluating another's social roles (Haidt \& Baron, 1996) } \\
\text { - Selection for intimacy (Clark \& Mills, 2012) } \\
\text { - Reinforcement (Kessler et al., 2010) }\end{array}$ \\
\hline $\begin{array}{l}\text { Judging from a concern } \\
\text { with personal welfare }\end{array}$ & $\begin{array}{l}\text { - Idealization / devaluation (Samuel \& Widiger, 2008) } \\
\text { - Upward social comparisons (to someone doing better) (Goethals \& Darley, 1977; Wood, } \\
\text { 1989) } \\
\text { - Downward social comparisons (to someone doing less well; as above) } \\
\end{array}$ \\
\hline $\begin{array}{l}\text { Judging from a concern } \\
\text { with the setting }\end{array}$ & $\begin{array}{l}\text { - Evaluating a person from cues in their environment (Gosling, Ko, Mannarelli, \& Morris, } \\
\text { 2002) } \\
\text { - Evaluating personality from clothing cues (Naumann, Vazire, Rentfrow, \& Gosling, } \\
\text { 2009) }\end{array}$ \\
\hline $\begin{array}{l}\text { Judging from a concern } \\
\text { with physical qualities }\end{array}$ & $\begin{array}{l}\text { - Risk assessment of health and contagion (Gangestad \& Scheyd, 2005) } \\
\text { - Assessment of reproductive possibilities (Gangestad \& Scheyd, 2005; Grammer, Fink, } \\
\text { Møller, \& Thornhill, 2003; Langlois et al., 2000; Peluchette, Karl, \& Rust, 2006) }\end{array}$ \\
\hline
\end{tabular}

A related application of the model is to psychotherapeutic processes. All of us find it difficult sometimes to accept the judgments of others - and this may be particularly challenging for people who suffer from certain mental disorders. Some individuals are particularly likely to react with defensiveness and sensitivity to the possibility of rejection. (B. London et al., 2007). By outlining the judgment process as we do here, and by disseminating this information, it could be possible to develop a cognitively-based clinical intervention that helps people by explaining the process of judgments and by training people in how to receive, understand, and use feedback adaptively.

\section{An Index of Psychological Functioning and Well-Being}

As a final example of the model's application, the Social Message Model may allow us to better understand the adaptive qualities of personality functioning by using the standards a person might meet or fail to meet as a yardstick. Psychologists, college admissions officers, and human resource personnel often look toward the overall adaptive quality of personality, and they do it quite well — but often using just a few important standards. Roberts et al. (2007) selected 
regularly-employed criteria of longevity, marital success, and occupational attainment to demonstrate the power of personality traits to predict highly valued outcomes. Others have chosen well-being (Diener, 1984; Diener, 2000), eudemonia (Ryff \& Singer, 2008), and lists of virtuous traits such as honesty, generosity and fairness (Isaacowitz, Vaillant, \& Seligman, 2003).

The Social Message Model implies that we might do better-with a meta- or überstandard of "many standards met" to provide a more global, general index of personality functioning. Briefly, a researcher could sample key standards from each of the areas outlined by the model: a person's physical qualities, physical surroundings (settings), situations faced, and group memberships, as well as those standards that pertain to the individual's psychological personality such as his or her extraversion or defensiveness. Measures for each area of standardmeeting then could be developed and the individual's performance in regard to meeting the standards calculated. An approach like this already is employed in life-report (also known as biodata) studies where people are asked about their education, marriage status, awards won, and other accomplishments (Breaugh, 2009; Mayer et al., 1998; Stokes, 1999).

Inner and outer standards. Few of us can meet all the standards we would like to in our lives. Success for most of us often depends on creating a synergy between the internal and external standards on which we choose to focus. Conforming exclusively to the standards of others at the expense of our own goals and identity is likely to be self-defeating. Contemporary research programs speak to the importance of both recognizing and adhering to one's inner motives and goals - important inner standards (Ryan et al., 2008; Sheldon \& Kasser, 1995). However, self-indulgence that leaves no room for negotiation with the needs of others also can lead in an unproductive direction. A person who successfully balances the social landscape with self-determined goals over the lifespan may do best.

Those who successfully strike the balance between inner and outer demands may reasonably be considered as higher on a continuum of optimal functioning relative to others, given roughly equivalent social contexts. Moreover, given that many of the standards we apply to one another are socially guided, people who meet both their inner standards by fulfilling their own motivations, and also meet many socially-imposed standards well, are likely to be honored in multiple ways by their family, friends, and community members.

Ecological validity. This standard-meeting index may possess considerable ecologically validity: We naturally seem to evaluate other people according to the standards they have met. When someone is described in a brief biographical description in a magazine, newspaper, book jacket or, finally, in an obituary, these depictions often depict standards met (e.g., "Harvard graduate, self-made, parented a large family with a loving spouse, eight grandchildren, successful amateur scientist, realized her own vision, and enjoyed it all..." (Johnson, 2006). Of course, we can find exceptions of people who seem to meet their own and others' goals and yet may not be happy. A person's emotion system can and does function in partial independence of such activities although, by-and-large, most people find it fulfilling to meet the standards they have identified and embraced.

\section{Concluding Comments}

Judgments of personality are pervasive; they are a key part of neighborhood and organizational gossip, media commentary on public figures, and professional assessments. In each of these areas, good judgments potentially help us adapt by providing us with information about our acts and status in a group (Baumeister et al., 2004; Dunbar, 2009). Commentary on people we know is often prosocial (Feinberg, Willer, Stellar, \& Keltner, 2012; Mayer \& Leichtman, 2012), and the discussion of personality can involve information-gathering and group 
motivations (Beersma \& Van Kleef, 2012). Clinical feedback of personality assessments also is therapeutic if delivered in a constructive and participatory fashion (Finn, 2005).

Since 2004, personality psychologists have shifted their interests visibly toward the study of self-knowledge and accurate person-perception (Dunning, 2005; Wilson \& Dunn, 2004; Wilson, 2009). Judging people and listening to how we are judged is central to developing awareness of ourselves and other people. Our well-being in multiple areas depends upon our being judged and our receptivity and reasoning about those judgments. If we want to be a good group member, we need to listen to the members of our group about how we behave. If we want to understand ourselves, we need to listen to how observers evaluate us. To maintain good relationships with other people, we need their feedback about our behavior in everyday interactions, and to remain true to ourselves, we need to compare our internal standards to the concerns and judgments of those around us. As Dunning and others have pointed out, we are not always good at this. But biases and mistakes in judgment don't mean that we never get it right. In fact, accuracy coexists with bias - as Funder and others have pointed out (Haselton \& Funder, 2006; Kenny, Snook, Boucher, \& Hancock, 2010). The model presented here provides a step in the direction of better understanding and maximizing the adaptive potential in the social judgment process. Interpersonal judgments are likely to be highly adaptive for us - if we understand them and their origins in the judge's concerns. Learning how to draw on the adaptive information of a judge's evaluation is an important skill — and we hope that ultimately this model will help people to get the messages that will help them.

\section{References}

Abelson, R. P. (1963). Computer simulations of "hot cognition.". In S. S. Tompkins, \& S. Messick (Eds.), Computer simulations of personality (pp. 277-302). New York: Wiley.

Andersen, S. M., \& Chen, S. (2002). The relational self: An interpersonal social-cognitive theory. Psychological Review, 109(4), 619-645. doi:10.1037/0033-295X.109.4.619

Andrews, P. W., Gangestad, S. W., \& Matthews, D. (2002). Adaptationism, exaptationism, and evolutionary behavioral science. Behavioral \& Brain Sciences, 25(4), 534. Retrieved from http://search.ebscohost.com/login.aspx?direct=true \&db=aph\&AN=10025703\&site=ehost$\underline{\text { live }}$

Bargh, J. A., Lombardi, W. J., \& Higgins, E. T. (1988). Automaticity of chronically accessible constructs in person $\times$ situation effects on person perception: It's just a matter of time. Journal of Personality and Social Psychology, 55(4), 599-605. doi:10.1037/00223514.55.4.599

Baumeister, R. F., \& Leary, M. R. (1995). The need to belong: Desire for interpersonal attachments as a fundamental human motivation. Psychological Bulletin, 117(3), 497-529. doi:10.1037/0033-2909.117.3.497

Baumeister, R. F., Zhang, L., \& Vohs, K. D. (2004). Gossip as cultural learning. Review of General Psychology, 8(2), 111-121. doi:10.1037/1089-2680.8.2.111

Beckhouse, L., Tanur, J., Weiler, J., \& Weinstein, E. (1975). . . And some men have leadership thrust upon them. Journal of Personality and Social Psychology, 31(3), 557-566. doi: $10.1037 / \mathrm{h} 0076478$

Beersma, B., \& Van Kleef, G. A. (2012). Why people gossip: An empirical analysis of social motives, antecedents, and consequences. Journal of Applied Social Psychology, 42(11), 2640-2670. Retrieved from http://search.ebscohost.com/login.aspx?direct=true \&db=psyh\&AN=2012-31128$\underline{002 \& \text { site }=\text { ehost-live }}$ 
Bem, S. L. (1984). Androgyny and gender schema theory: A conceptual and empirical integration. Nebraska Symposium on Motivation, 32, 179-226. Retrieved from http://search.ebscohost.com/login.aspx?direct=true\&db=psyh\&AN=1989-29108001\&site $=$ ehost-live

Ben-Ze'ev, A. (1994). The vindication of gossip. In A. Ben-Ze'ev (Ed.), Good gossip (pp. 11-24). Lawrence, KS US: University Press of Kansas. Retrieved from http://search.ebscohost.com/login.aspx?direct=true\&db=psyh\&AN=1994-98161$\underline{001 \& \text { site }=\text { ehost-live }}$

Bond, M., Gardner, S. T., Christian, J., \& Sigal, J. J. (1983). Empirical study of self-rated defense styles. Archives of General Psychiatry, 40(3), 333-338. Retrieved from http://search.ebscohost.com/login.aspx?direct=true \&db=cmedm\&AN=6830412\&site=ehost$\underline{\text { live }}$

Bonnefon, J., \& Villejoubert, G. (2006). Tactful or doubtful?: Expectations of politeness explain the severity bias in the interpretation of probability phrases. Psychological Science, 17(9), 747-751. doi:10.1111/j.1467-9280.2006.01776.x

Breaugh, J. A. (2009). The use of biodata for employee selection: Past research and future directions. Human Resource Management Review, 19(3), 219-231. doi:10.1016/j.hrmr.2009.02.003

Brenner, C. (2003). Is the structural model still useful? The International Journal of Psychoanalysis, 84(5), 1093-1096. doi:10.1516/HPY0-6VCD-9JEX-HX50

Brewer, M. B., \& Gardner, W. (1996). Who is this 'we'? levels of collective identity and self representations. Journal of Personality and Social Psychology, 71(1), 83-93. doi:10.1037/0022-3514.71.1.83

Buhrmester, D., Furman, W., Wittenberg, M. T., \& Reis, H. T. (1988). Five domains of interpersonal competence in peer relationships. Journal of Personality and Social Psychology, 55(6), 991-1008. doi:10.1037/0022-3514.55.6.991

Chan, E., \& Sengupta, J. (2010). Insincere flattery actually works: A dual attitudes perspective. Journal of Marketing Research, 47(1), 122-133. doi:10.1509/jmkr.47.1.122

Christian, M. S., Edwards, B. D., \& Bradley, J. C. (2010). Situational judgment tests: Constructs assessed and a meta-analysis of their criterion-related validities. Personnel Psychology, 63(1), 83-117. doi:10.1111/j.1744-6570.2009.01163.x

Christiansen, N. D., Wolcott-Burnam, S., Janovics, J. E., Burns, G. N., \& Quirk, S. W. (2005). The good judge revisited: Individual differences in the accuracy of personality judgments. Human Performance, 18(2), 123-149. doi:10.1207/s15327043hup1802_2

Clark, M. S., \& Mills, J. R. (2012). A theory of communal (and exchange) relationships. In P. A. M. Van Lange, A. W. Kruglanski \& E. T. Higgins (Eds.), Handbook of theories of social psychology (vol 2). (pp. 232-250). Thousand Oaks, CA: Sage Publications Ltd. Retrieved from http://search.ebscohost.com/login.aspx?direct=true \&db=psyh\&AN=2011-21802$\underline{013 \& \text { site }=\text { ehost-live }}$

Diener, E. (1984). Subjective well-being. Psychological Bulletin, 95(3), 542-575. Retrieved from http://search.ebscohost.com/login.aspx?direct=true\&db=cmedm\&AN=6399758\&site=ehost$\underline{\text { live }}$

Diener, E. (2000). Subjective well-being. the science of happiness and a proposal for a national index. The American Psychologist, 55(1), 34-43. Retrieved from http://search.ebscohost.com/login.aspx?direct=true\&db=cmedm\&AN=11392863\&site=ehos t-live 
Downey, G., \& Feldman, S. I. (1996). Implications of rejection sensitivity for intimate relationships. Journal of Personality and Social Psychology, 70(6), 1327-1343. doi:10.1037/0022-3514.70.6.1327

Dunbar, R. I. M. (2009). The social brain hypothesis and its implications for social evolution. Annals of Human Biology, 36(5), 562-572. doi:10.1080/03014460902960289

Dunning, D. (2005). Self-insight: Roadblocks and detours on the path to knowing thyself. New York, NY US: Psychology Press.

Feinberg, M., Willer, R., Stellar, J., \& Keltner, D. (2012). The virtues of gossip: Reputational information sharing as prosocial behavior. Journal of Personality and Social Psychology, 102(5), 1015-1030. Retrieved from http://search.ebscohost.com/login.aspx?direct=true\&db=psyh\&AN=2012-00030$001 \&$ site $=$ ehost-live

Festinger, L. (1954). A theory of social comparison processes. Human Relations, 7, 117-140. doi:10.1177/001872675400700202

Finn, S. E. (2005). How psychological assessment taught me compassion and firmness. Journal of Personality Assessment, 84(1), 29-32. doi:10.1207/s15327752jpa8401_07

Fiske, S. T. (1992). Thinking is for doing: Portraits of social cognition from daguerreotype to laserphoto. Journal of Personality and Social Psychology, 63(6), 877-889. Retrieved from http://search.ebscohost.com/login.aspx?direct=true\&db=psyh\&AN=1993-13481001\&site $=$ ehost-live

Fiske, S. T. (1993). Social cognition and social perception. Annual Review of Psychology, 44, 155-194. doi:10.1146/annurev.ps.44.020193.001103

Fiske, S. T., \& Taylor, S. E. (1991). Social cognition (2nd ed.). New York, NY, England: Mcgraw-Hill Book Company. Retrieved from http://search.ebscohost.com/login.aspx?direct=true\&db=psyh\&AN=1991-97723000\&site $=$ ehost-live

Forgas, J. P., \& Bower, G. H. (2001). Mood effects on person-perception judgments. In W. G. Parrott, \& W. G. Parrott (Eds.), Emotions in social psychology: Essential readings. (pp. 204-215). New York, NY US: Psychology Press. Retrieved from http://search.ebscohost.com/login.aspx?direct=true\&db=psyh\&AN=2000-12576011\&site $=$ ehost-live

Freeman, J. B., \& Ambady, N. (2011). A dynamic interactive theory of person construal. Psychological Review, 118(2), 247-279. doi:10.1037/a0022327

Freud, S. (1962). Civilization and its discontents. New York, NY: W.W. Norton.

Funder, D. C. (1995). On the accuracy of personality judgment: A realistic approach. Psychological Review, 102(4), 652-670. doi:10.1037/0033-295X.102.4.652

Funder, D. C. (2001). Accuracy in personality judgment: Research and theory concerning an obvious question. In R. Hogan (Ed.), Personality psychology in the workplace. (pp. 121140). Washington, DC US: American Psychological Association. doi:10.1037/10434-005

Gangestad, S. W., \& Scheyd, G. J. (2005). The evolution of human physical attractiveness. Annual Review of Anthropology, 34, 523-548. doi:10.1146/annurev.anthro.33.070203.143733

Garcia, J. L. A. (1995). Intention-sensitive ethics. Public Affairs Quarterly, 9(3), 201-213. Retrieved from http://search.ebscohost.com/login.aspx?direct=true \&db=phl\&AN=PHL1640672\&site=ehost $\underline{\text {-live }}$ 
Gosling, S. D., Ko, S. J., Mannarelli, T., \& Morris, M. E. (2002). A room with a cue: Personality judgments based on offices and bedrooms. Journal of Personality and Social Psychology, 82(3), 379-398. doi:10.1037/0022-3514.82.3.379

Gresham, F. M., Elliott, S. N., Cook, C. R., Vance, M. J., \& Kettler, R. (2010). Cross-informant agreement for ratings for social skill and problem behavior ratings: An investigation of the social skills improvement System-Rating scales. Psychological Assessment, 22(1), 157166. doi:10.1037/a0018124

Haidt, J., \& Baron, J. (1996). Social roles and the moral judgement of acts and omissions. European Journal of Social Psychology, 26(2), 201-218. Retrieved from http://search.ebscohost.com/login.aspx?direct=true\&db=aph\&AN=14155595\&site=ehost$\underline{\text { live }}$

Haidt, J., \& Joseph, C. (2004). Intuitive ethics: How innately prepared intuitions generate culturally variable virtues. Daedalus, 133(4), 55-66. Retrieved from http://search.ebscohost.com/login.aspx?direct=true \&db=aph\&AN=15115055\&site=ehost$\underline{\text { live }}$

Hardin, C. D., \& Higgins, E. T. (1996). Shared reality: How social verification makes the subjective objective. In R. M. Sorrentino, \& E. T. Higgins (Eds.), (pp. 28-84). New York, NY, US: Guilford Press. Retrieved from http://search.ebscohost.com/login.aspx?direct=true\&db=psyh\&AN=1996-98385$\underline{002 \& \text { site }=\text { ehost-live }}$

Haselton, M. G., \& Funder, D. C. (2006). The evolution of accuracy and bias in social judgment. In D. T. Kenrick (Ed.), Evolution and social psychology. (pp. 15-37). Madison, CT US: Psychosocial Press.

Isaacowitz, D. M., Vaillant, G. E., \& Seligman, M. E. P. (2003). Strengths and satisfaction across the adult lifespan. International Journal of Aging \& Human Development, 57(2), 181-201.

Retrieved from http://search.ebscohost.com/login.aspx?direct=true \&db=aph\&AN=12942081\&site=ehost$\underline{\text { live }}$

Jarymowicz, M. (1992). Self, we, and other(s): Schemata, distinctiveness, and altruism. In P. M. Oliner, S. P. Oliner, L. Baron, L. A. Blum, D. L. Krebs \& M. Z. Smolenska (Eds.), Embracing the other: Philosophical, psychological, and historical perspectives on altruism. (pp. 194-212). New York, NY US: New York University Press. Retrieved from http://search.ebscohost.com/login.aspx?direct=true\&db=psyh\&AN=1993-97129008\& site $=$ ehost-live

Johnson, M. (2006). The dead beat: Lost souls, lucky stiffs, and the perverse pleasures of obituaries. New York, NY: HarperCollins.

Kamins, M. L., \& Dweck, C. S. (1999). Person versus process praise and criticism: Implications for contingent self-worth and coping. Developmental Psychology, 35(3), 835-847. doi:10.1037/0012-1649.35.3.835

Kane, P. E. (1992). Errors, lies, and libel. Carbondale, IL: Southern Illinois University Press. Kawada, C. L. K., Oettingen, G., Gollwitzer, P. M., \& Bargh, J. A. (2004). The projection of implicit and explicit goals. Journal of Personality and Social Psychology, 86(4), 545-559. Retrieved from http://search.ebscohost.com/login.aspx?direct=true \&db=psyh\&AN=200412052-003\&site=ehost-live

Kenny, D. A., Snook, A., Boucher, E. M., \& Hancock, J. T. (2010). Interpersonal sensitivity, status, and stereotype accuracy. Psychological Science, 21(12), 1735-1739. 
Kenny, D. A., \& West, T. V. (2010). Similarity and agreement in self- and other perception: A meta-analysis. Personality and Social Psychology Review, 14(2), 196-213. doi:10.1177/1088868309353414

Kipnis, L. (2010). How to become a scandal: Adventures in bad behavior. New York, NY: Metropolitan Books.

Klinger, E., \& Cox, W. M. (2004). Motivation and the theory of current concerns. In W. M. Cox, \& E. Klinger (Eds.), (pp. 3-27). New York, NY, US: John Wiley \& Sons Ltd. Retrieved from http://search.ebscohost.com/login.aspx?direct=true\&db=psyh\&AN=2004-12476$001 \&$ site $=$ ehost-live

Kopetz, C. E., Kruglanski, A. W., Chen, X., \& Orehek, E. (2008). Goal systemic effects in the context of choice and social judgment. Social and Personality Psychology Compass, 2(6), 2071-2089. Retrieved from http://search.ebscohost.com/login.aspx?direct=true \&db=psyh\&AN=2010-03168001\&site=ehost-live

Langlois, J. H., Kalakanis, L., Rubenstein, A. J., Larson, A., Hallam, M., \& Smoot, M. (2000). Maxims or myths of beauty? A meta-analytic and theoretical review. Psychological Bulletin, 126(3), 390-423. doi:10.1037/0033-2909.126.3.390

Letzring, T. D. (2008). The good judge of personality: Characteristics, behaviors, and observer accuracy. Journal of Research in Personality, 42(4), 914-932. doi:10.1016/j.jrp.2007.12.003

Link, B. G., \& Phelan, J. C. (2001). Conceptualizing stigma. Annual Review of Sociology, 27, 363-385. doi:10.1146/annurev.soc.27.1.363

London, B., Downey, G., Bonica, C., \& Paltin, I. (2007). Social causes and consequences of rejection sensitivity. Journal of Research on Adolescence, 17(3), 481-506. doi:10.1111/j.1532-7795.2007.00531.x

London, M. (2002). Leadership development: Paths to self-insight and professional growth. Mahwah, NJ US: Lawrence Erlbaum Associates Publishers. Retrieved from http://search.ebscohost.com/login.aspx?direct=true\&db=psyh\&AN=2001-18828$\underline{000 \& \text { site }=\text { ehost-live }}$

Luhtanen, R., \& Crocker, J. (1992). A collective self-esteem scale: Self-evaluation of one's social identity. Personality and Social Psychology Bulletin, 18(3), 302-318. doi:10.1177/0146167292183006

Maccoby, E. E. (2007). Historical overview of socialization research and theory. In J. E. Grusec, \& P. D. Hastings (Eds.), Handbook of socialization: Theory and research. (pp. 13-41). New York, NY US: Guilford Press. Retrieved from http://search.ebscohost.com/login.aspx?direct=true \&db=psyh\&AN=2006-23344001\&site=ehost-live

Mayer, J. D. (2005). A tale of two visions: Can a new view of personality help integrate psychology? American Psychologist, 60(4), 294-307. doi:10.1037/0003-066X.60.4.294

Mayer, J. D. (2014). Personal intelligence: The power of personality and how it shapes our lives. New York: Scientific American / Farrar Strauss \& Giroux.

Mayer, J. D., Carlsmith, K. M., \& Chabot, H. F. (1998). Describing the person's external environment: Conceptualizing and measuring the life space. Journal of Research in Personality, 32(3), 253-296. doi:10.1006/jrpe.1998.2220

Mayer, J. D., \& Lang, J. L. (2011). A three-dimensional view of personality. Psychological Inquiry, 22(1), 36-39. doi:10.1080/1047840X.2011.544635 
Mayer, J. D., \& Leichtman, M. D. (2012). Saddam hussein is "dangerous to the extreme": The ethics of professional commentary on public figures. Psychology of Popular Media Culture, 1(1), 3-22. doi:10.1037/a0027253

Mayer, J. D., Panter, A. T., \& Caruso, D. R. (2012). Does personal intelligence exist? evidence from a new ability-based measure. Journal of Personality Assessment, 94, 124-140. doi:10.1080/00223891.2011.646108

Mayer, J. D., Roberts, R. D., \& Barsade, S. G. (2008). Human abilities: Emotional intelligence. Annual Review of Psychology, 59, 507-536. doi:10.1146/annurev.psych.59.103006.093646

McAdams, D. P., \& Pals, J. L. (2006). A new big five: Fundamental principles for an integrative science of personality. American Psychologist, 61(3), 204-217. doi:10.1037/0003066X.61.3.204

McCallum, M., \& Piper, W. E. (1990). The psychological mindedness assessment procedure. Psychological Assessment: A Journal of Consulting and Clinical Psychology, 2(4), 412-418. doi:10.1037/1040-3590.2.4.412

Mischel, W., \& Shoda, Y. (1995). A cognitive-affective system theory of personality: Reconceptualizing situations, dispositions, dynamics, and invariance in personality structure. Psychological Review, 102(2), 246-268. doi:10.1037/0033-295X.102.2.246

Naumann, L. P., Vazire, S., Rentfrow, P. J., \& Gosling, S. D. (2009). Personality judgments based on physical appearance. Personality and Social Psychology Bulletin, 35(12), 16611671. doi:10.1177/0146167209346309

Olson, K. R., \& Dweck, C. S. (2009). Social cognitive development: A new look. Child Development Perspectives, 3(1), 60-65. doi:10.1111/j.1750-8606.2008.00078.x

Oyserman, D. (2009). Identity-based motivation: Implications for action-readiness, proceduralreadiness, and consumer behavior. Journal of Consumer Psychology, 19(3), 250-260. doi:10.1016/j.jcps.2009.05.008

Palomares, N. A. (2004). Gender schematicity, gender identity salience, and gender-linked language use. Human Communication Research, 30(4), 556-588. doi:10.1111/j.14682958.2004.tb00745.x

Phillips, T., \& Smith, P. (2008). Cosmopolitan beliefs and cosmopolitan practices: An empirical investigation. Journal of Sociology, 44(4), 391-399. doi:10.1177/1440783308097128

Pratkanis, A. R., \& Gliner, M. D. (2004). And when shall a little child lead them? evidence for an altercasting theory of source credibility. Current Psychology, 23(4), 279-304. Retrieved from http://search.ebscohost.com/login.aspx?direct=true \&db=bch\&AN=18020448\&site=ehostlive

Rawls, J. (1971). A theory of justice. Cambridge, MA: Belknap Press of Harvard University Press.

Roberts, B. W., Kuncel, N. R., Shiner, R., Caspi, A., \& Goldberg, L. R. (2007). The power of personality: The comparative validity of personality traits, socioeconomic status, and cognitive ability for predicting important life outcomes. Perspectives on Psychological Science, 2(4), 313-345. doi:10.1111/j.1745-6916.2007.00047.x

Ryan, R. M., \& Deci, E. L. (2000). Self-determination theory and the facilitation of intrinsic motivation, social development, and well-being. American Psychologist, 55(1), 68-78. doi:10.1037/0003-066X.55.1.68 
Ryan, R. M., Huta, V., \& Deci, E. L. (2008). Living well: A self-determination theory perspective on eudaimonia. Journal of Happiness Studies, 9(1), 139-170. doi:10.1007/s10902-006-9023-4

Ryff, C. D., \& Singer, B. H. (2008). Know thyself and become what you are: A eudaimonic approach to psychological well-being. Journal of Happiness Studies, 9(1), 13-39. doi:10.1007/s10902-006-9019-0

Schwartz, S. H., \& Boehnke, K. (2004). Evaluating the structure of human values with confirmatory factor analysis. Journal of Research in Personality, 38(3), 230-255. doi:10.1016/S0092-6566(03)00069-2

Sheldon, K. M. (2011). Consilience within the biopsychosocial system. Psychological Inquiry, 22(1), 52-65. doi:10.1080/1047840X.2011.551105

Sheldon, K. M., \& Kasser, T. (1995). Coherence and congruence: Two aspects of personality integration. Journal of Personality and Social Psychology, 68(3), 531-543.

Skinner, N., \& Brewer, N. (2004). Adaptive approaches to competition: Challenge appraisals and positive emotion. Journal of Sport \& Exercise Psychology, 26(2), 283-305.

Smetana, J. G. (1999). The role of parents in moral development: A social domain analysis. Journal of Moral Education, 28(3), 311-321. Retrieved from http://search.ebscohost.com/login.aspx?direct=true \&db=psyh\&AN=2005-11240005\&site $=$ ehost-live

Smith, C. A., Haynes, K. N., Lazarus, R. S., \& Pope, L. K. (1993). In search of the 'hot' cognitions: Attributions, appraisals, and their relation to emotion. Journal of Personality and Social Psychology, 65(5), 916-929. doi:10.1037/0022-3514.65.5.916

Smith, E. R., \& Collins, E. C. (2009). Contextualizing person perception: Distributed social cognition. Psychological Review, 116(2), 343-364. doi:10.1037/a0015072

Solomon, M. R., Ashmore, R. D., \& Longo, L. C. (1992). The beauty match-up hypothesis: Congruence between types of beauty and product images in advertising. Journal of Advertising, 21(4), 23-34. Retrieved from http://search.ebscohost.com/login.aspx?direct=true \&db=psyh\&AN=1993-27780001\&site $=$ ehost-live

Spence, J. T. (1993). Gender-related traits and gender ideology: Evidence for a multifactorial theory. Journal of Personality and Social Psychology, 64(4), 624-635. doi:10.1037/00223514.64.4.624

Stern, C., West, T. V., \& Schoenthaler, A. (2013). The dynamic relationship between accuracy and bias in social perception research. Social and Personality Psychology Compass, 7(5), 303-314. Retrieved from http://search.ebscohost.com/login.aspx?direct=true\&db=psyh\&AN=2013-19373004\&site $=$ ehost-live

Stiff, C., \& Van Vugt, M. (2008). The power of reputations: The role of third party information in the admission of new group members. Group Dynamics: Theory, Research, and Practice, 12(2), 155-166. doi:10.1037/1089-2699.12.2.155

Stokes, G. S. (1999). Introduction to special issue: The next one hundred years of biodata. Human Resource Management Review, 9(2), 111-116. doi:10.1016/S1053-4822(99)00014-5

Swann, W. B. (1984). Quest for accuracy in person perception: A matter of pragmatics. Psychological Review, 91(4), 457-477. doi:10.1037/0033-295X.91.4.457

Tajfel, H. (1982). Social psychology of intergroup relations. Annual Review of Psychology, 33, 1. Retrieved from 
http://search.ebscohost.com/login.aspx?direct=true \&db=aph\&AN=11268157\&site=ehost$\underline{\text { live }}$

Tetlock, P. E. (2002). Social functionalist frameworks for judgment and choice: Intuitive politicians, theologians, and prosecutors. Psychological Review, 109(3), 451-471. Retrieved from http://search.ebscohost.com/login. aspx?direct=true \&db=psyh\&AN=2002-13781001\&site=ehost-live

Vaillant, G. E., Bond, M., \& Vaillant, C. O. (1986). An empirically validated hierarchy of defense mechanisms. Archives of General Psychiatry, 43(8), 786-794. Retrieved from http://search.ebscohost.com/login.aspx?direct=true \&db=psyh\&AN=1987-00885$001 \&$ site $=$ ehost-live

Vonk, R. (2002). Self-serving interpretations of flattery: Why ingratiation works. Journal of Personality and Social Psychology, 82(4), 515-526. doi:10.1037/0022-3514.82.4.515

Wilson, T. D. (2009). Know thyself. Perspectives on Psychological Science (Wiley-Blackwell), 4(4), 384-389. doi:10.1111/j.1745-6924.2009.01143.x

Wilson, T. D., \& Dunn, E. W. (2004). Self-knowledge: Its limits, value and potential for improvement. Annual Review of Psychology, 55, 493-518. doi:10.1146/annurev.psych.55.090902.141954

Wood, J. V. (1989). Theory and research concerning social comparisons of personal attributes. Psychological Bulletin, 106(2), 231-248. doi:10.1037/0033-2909.106.2.231 